Article

\title{
Analytical Comparison of German Owner's Budget Estimate and Chinese Contractor's Bid: A Case Study for a Warehouse Building Project in China
}

\author{
Gen Li ${ }^{1,2}$ and Rong $X u^{1, *}$
}

Citation: Li, G.; Xu, R. Analytical Comparison of German Owner's Budget Estimate and Chinese Contractor's Bid: A Case Study for a Warehouse Building Project in China. Sustainability 2022, 14, 970. https:// doi.org/10.3390/su14020970

Academic Editors: Pierfrancesco De Paola and Eul-Bum Lee

Received: 24 September 2021

Accepted: 11 January 2022

Published: 15 January 2022

Publisher's Note: MDPI stays neutral with regard to jurisdictional claims in published maps and institutional affiliations.

Copyright: (C) 2022 by the authors. Licensee MDPI, Basel, Switzerland. This article is an open access article distributed under the terms and conditions of the Creative Commons Attribution (CC BY) license (https:// creativecommons.org/licenses/by/ $4.0 /)$.

\author{
1 Department of Structural Engineering, Tongji University, Shanghai 200092,China; tj_ligen@tongji.edu.cn \\ 2 Siemens Real Estate, Siemens Ltd., Shanghai 200082, China \\ * Correspondence: xurong@tongji.edu.cn; Tel.: +86-021-65985998
}

\begin{abstract}
Nowadays, the need for scientific and modernized engineering cost management has been increasingly prominent. Hence, this study compared the differences of the quantities' terms, the management philosophy, the related institutions (or specifications), and other factors in engineering cost management between China and Germany accompanied by a case study for a warehouse building project in China. There are two main parts. Firstly, according to the literature research, the comparative analysis was conducted on the engineering cost-control mode, the list of bills of quantities, and other parameters between China and Germany. On the basis of this, the "differences" between China and Germany especially in the bidding process were further studied with the empirical analysis of engineering cases, which is a supplementary argument to the theoretical analysis. Finally, several related suggestions were put forward, including proposing a set of "universal" bills of quantities (which can be understood by Chinese enterprises and also accepted by foreign-funded enterprises), the establishment of the whole process, a dynamic and information-based project cost-management system, cultivation of talents with the advanced management concept, and the development of international engineering companies and project-management companies with core competitiveness. The conclusions are expected to provide some references for China's construction industry to further expand the international market and to increase the influences in global markets.
\end{abstract}

Keywords: cost management; project management; German engineering cost; comparative analysis; bills of quantities (BQ); cost estimate

\section{Introduction}

The report of the 19th National Congress of the Communist Party of China clearly pointed out that China's economy has transformed from a high-speed growth stage to a high-quality development stage. As one of the pillar industries, the construction industry plays a key role in promoting socio-economic development (not only in China but also in the whole world [1,2]). Meanwhile, the coming of construction 4.0 and the entering of a new century in the construction industry [3-5] both indicate that the whole industry is facing great reform and challenge. As the most basic economic activity in the construction market, the project cost plays the vital role in project investment benefits, construction market order, and national economic development [6-9].

With the development of China's economy, China's engineering cost project mode has gone through several stages since the founding of New China [10-12]: (1) a construction project quota pattern based on the Soviet pattern; (2) the construction mode with the principle of "controlled quantity, opened price, introduced competition"; (3) the mode marked by the publication of "the Code of related with bill quantity of construction." With the continuous development of economic globalization and the deepening of policies such as "opening to the outside world" and "the Belt and Road Initiative," for the domestic construction 
industry, it not only brings opportunities for learning, progressing, and reforming to the development but also brings challenges from foreign-capitalist-developed countries.

Germany, as an old industrial power, plays an important role in the global construction industry and industrial market. "Made in Germany" has become an iconic example characterized with durability, reliability, safety, and precision. One of the typical examples is Siemens Company. Although Siemens is not a typical construction enterprise, early in the 1880s Siemens entered the domestic market, and in 1899 it invested in Beijing to build China's first power plant. Up to now, its business has expanded to engineering construction, driving technology, energy technology, transportation construction, and other aspects [13]. The production and operation of Siemens are inseparable from the plant construction, hence the real-estate management department was specially set up for this purpose. Siemens investment in China has increased rapidly year by year, and its projects in China have also increased simultaneously. Therefore, the comparative study of engineering costs between China and Germany has strong practical engineering significance.

It should be noted that the construction-project cost-management modes implemented by the United States, Japan, and the UK are internationally recognized [14,15]. Taking AACE (the abbreviation of "American Association of Cost Engineers," and the website accessed on 1 January 2022 is: https:/ /web.aacei.org/about-aace) as an example, it has played a key role as the leading authority on costing not only in the United States but also around the world. After its founding in 1956, it has already had more than 6000 members by the 1980s. Now it is with membership extending to more than 80 countries worldwide and has grown to become an international organization with chapters in more than 20 countries. AACE's system encompasses many aspects that can be regarded as an integrated approach to portfolio, program, and project management and gives recommended practices in practical engineering. The Royal Institute of Chartered Surveyors (RICS, website accessed on 1 January 2022: https://www.rics.org/nl/), which is the typical representative of the British mode, is a widely and consistently recognized professional institute worldwide, with expertise in 17 different sectors including land, property, construction, project management, and environment. With a history of over 140 years, RICS now has more than 140,000 members in over 140 countries and publishes more than 500 research and public-policy reviews each year. The RICS is supported by more than 50 local associations and consortia around the world, and its authority is unquestionable.

As far as the current researches are concerned, most scholars focus on the project-cost system in Britain [16], America [17], and Japan [18]. At the same time, many studies focus on new technologies, new methods, and new solutions. For example, accompanied by the existence of Engineering Procurement Construction (EPC), Kim et al. [19] proposed a new model used for EPC that can effectively assess the trade-off between said resources and cost-risk mitigation. Some scholars [20-23] focused on the topic of risk and prediction, in which many mathematical methods, especially the probability model, are adopted. Moreover, considering "carbon neutrality," which is one of the hottest topics nowadays, some researchers [24] put the emphasis on the project cost management in the sustainable construction projects. Considering the globalization in the construction industry, some scholars [22,25] have already understood the importance and urgent need of comparing polices and management methods between different countries. To some extent, the relevant studies on project cost seem to be sufficient, abundant, comprehensive, and all-sided. However, the research on the German engineering cost system mode represented by German enterprises, which also has an important position in the global engineering field, is relatively little, let alone the comparative analysis between German mode and other patterns $[17,26-31]$. Although some scholars have carried out a series of studies on the comparison between China and Germany, there are still some limitations that deserve further in-depth discussion:

(1) The published time of relevant studies is generally early. With the rapid development of environmental ecology such as systems, national policy, and economic development, the previous studies have relatively weak correlation [26,27]. 
(2) At present, most of the comparative studies on project-cost analysis focus on the whole "system," meaning that their positions and perspectives are mostly limited to one of the participants in construction projects (such as consulting companies [28], construction units [29], construction organization [30], etc.). Construction projects have the characteristics of a long construction period, numerous participating units, and a complex interface relationship $[17,31]$. Compared with other research topics, there are relatively fewer studies about the interfaces and relationship between various units and participants in China, and there is also a lack of empirical research on engineering cases based on theoretical analysis of China and Germany.

In conclusion, under the background of the continuous optimization and development of the construction industry, this study conducted an in-depth analysis and a comparative study on the cost management (especially in cost estimate) of engineering construction projects between China and Germany, which took the new warehouse project of Siemens as an actual engineering case. It is hoped that this study can provide some references for China's construction industry to further expand the international market and increase the global share of the construction industry.

\section{Comparative Analysis Based on Literature Research}

The discussion ("Methodology and Analysis Process/Approach" or the main analysis logic of this study) includes several parts (Figure 1).

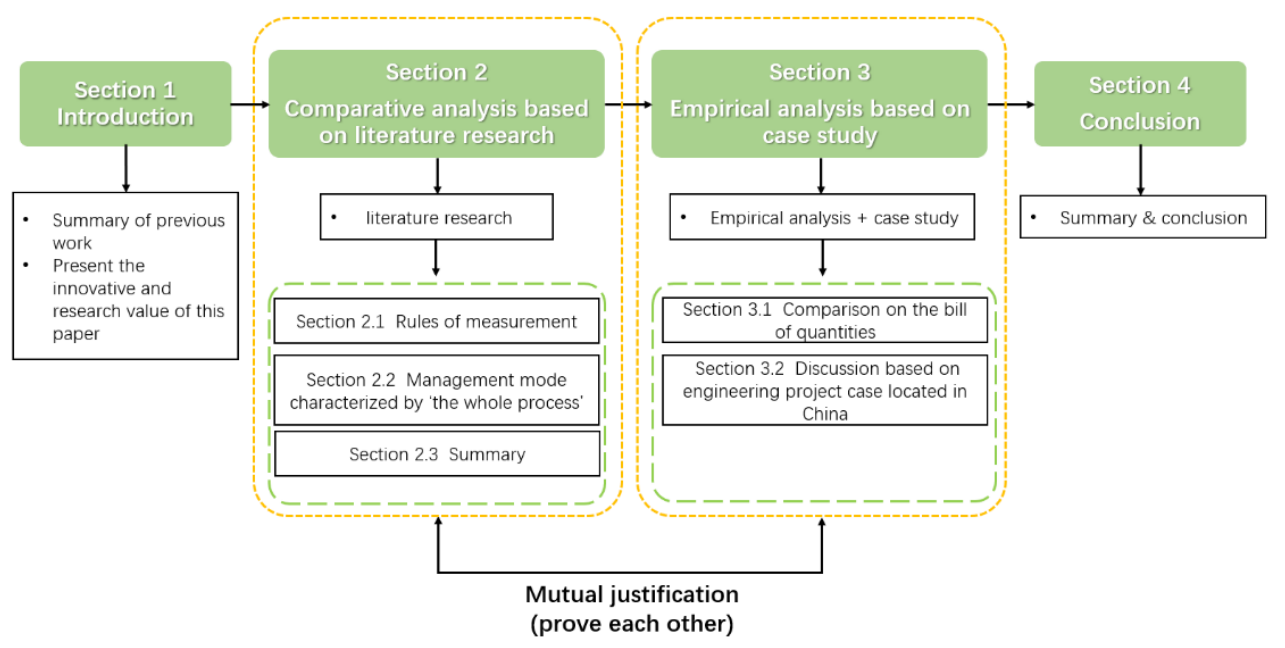

Figure 1. Methodology and analysis process/approach (the main-analysis logic).

First of all, as shown in the previous content, Section 1 (Introduction) of this article is for summarizing the previous work and presenting the importance and innovation of this study.

Secondly, Section 2 (Comparative analysis based on literature research) is mainly focused on the literature research by conducting a relevant theoretical analysis and summarizing published articles as well as national policy documents that can be found on socially oriented public web-sites. The differentiated analysis between China and Germany on the engineering cost mode at the theoretical level is fully studied, while providing theoretical full support for the subsequent empirical analysis in Section 3.

A detailed comparison of the measurement rules is made in Section 2.1. Specifically, the basic components of the bill of quantities, and the usage of the dynamic measurement method are analyzed. Further, the differences between the Chinese and German management modes are compared in depth with the whole-process management concept (Section 2.2). The results of the theoretical analysis are presented in the form of a table (Section 2.3). It can be seen that there are four main differences: the calculation of works, the determination of the unit price, the management mode, and the actual processing. 
Thirdly, the empirical analysis based on the case study is presented in Section 3. Section 3.1 presents an empirical analysis that took the new warehouse project of Siemens in Shenyang as an example, which further investigated the differences between China and Germany in project-cost management and control (especially in cost estimate). Combining with actual engineering cases and the content of previous theoretical analysis, on the one hand, the correctness of the conclusions of the theoretical analysis can be verified; on the other hand, the problems that are not covered in the theoretical analysis can be supplemented, forming a complete conclusion accompanied by literature studies. On this basis, relevant suggestions for the improvement of China's engineering cost-management model are put forward (Section 3.2).

Finally, Section 4 is the summary and conclusion of this article.

\subsection{Rules of Measurement}

\subsubsection{Basic Composition of BQ (Bills of Quantities)}

All-round reform and opening-up, China's second revolution if you like, has not only profoundly changed the China's economic development but has also greatly influenced the whole construction industry and engineering field. The economic system has transformed from a previous planned-economy to the socialist market economy with Chinese characteristics, and, at the same time, the management and regulation of the construction market has increasingly developed and improved. In terms of the process of determining project cost, there is little difference between China and other capitalist countries (not only including developed countries, which are with the most-recognized project-cost-management-modes, such as Britain, the US, and Japan, but also involving some industrial countries that have important positions in the global engineering field such as Germany).

In terms of the basic composition, the bills of quantities (BQ) list in Germany is mainly composed of the following three aspects (Figure 2) [32]: quotation of contractor, unexpected expenses, and proprietor administrative expenses. The quotation of contractor can be further divided into three parts, which are the direct fees, the indirect fees, and the other fees. The proprietor administrative expense is to pay for management work in the project. The unexpected expense is reserved for possible transfers and adjustments in the project or various claims for compensation that may be proposed by the contractor. It should be noted that the unexpected expense is one of the most-important parts that are seriously considered in the whole process of project cost control. Once the total sum of the whole project cost is determined and confirmed, the cost in practice shall not be allowed to exceed this amount. Hence, all the expenses in the project cost management, especially including the unexpected expense, shall be considered in detail, and the changes shall be avoided as much as possible, which is also the embodiment of "preciseness" in the German thinking mode.

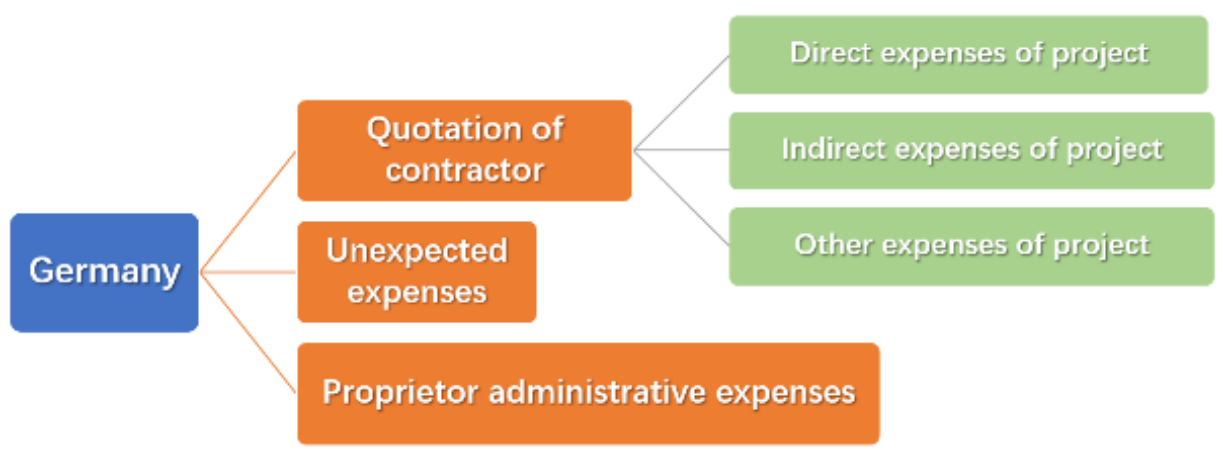

Figure 2. Constitutions of BQ (Germany).

As shown in Figures 2 and 3 (based on Chinese specification: Code of bills of quantities and valuation for construction works, GB50500-2013), it is clear that the basic compositions of the engineering bill of quantities in Germany and China are different. However, for 
a certain engineering project, no matter which measurement method is adopted, as long as the unit price (such as labor, material, construction machine, etc.) is the same, the calculated engineering cost shall be the same in principle. On the one hand, various measurement methods are just different "weapons," which will not make changes in the final results. On the other hand, if considering from the point of maneuverability, efficiency, and practicability, this kind of difference indeed brings in the inconvenience to the actual project: (1) Whether foreign-funded enterprises invest in construction projects in China, or Chinese construction enterprises carry out engineering activities in Germany and other countries that regard the German project-cost system as the main reference, the project-cost management unit (or preparation unit for bills of quantities) needs to formulate two sets of seemingly different and actually consistent lists of items for different groups to carry out pricing and valuating activities; (2) in each stage of the project process, each participating unit may adopt different measurement methods, which leads to the need for participating units in the next stage to re-formulate a set of lists applicable for their stages according to the previous link. The issues listed above are also the major practical needs that all foreign-funded enterprises face when entering the Chinese engineering market or when Chinese construction enterprises develop internationally and go outside.

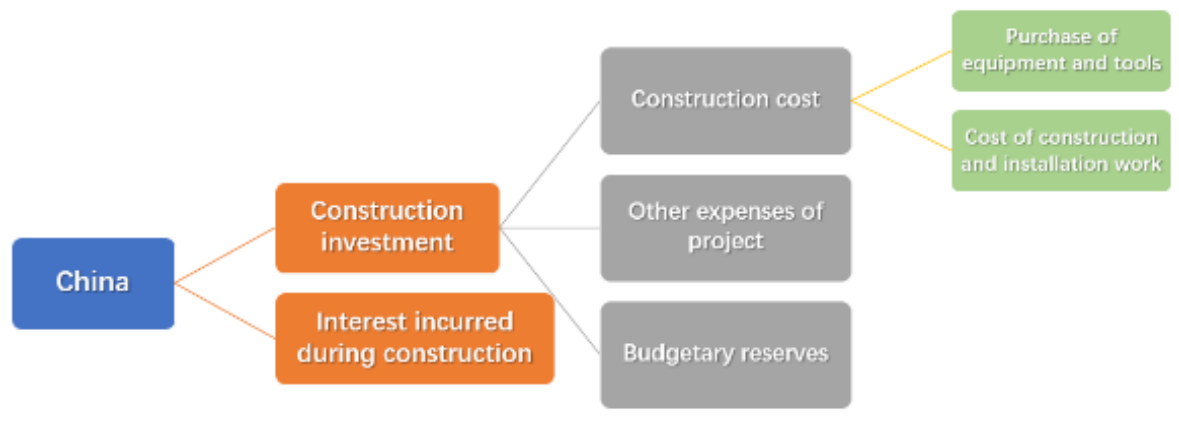

Figure 3. Constitutions of BQ (China).

In particular, the bid inviter will mostly provide the template of BQ used by the owner in the bidding process. However, in the projects undertaken by large foreign-funded enterprises represented by Siemens and $\mathrm{M}+\mathrm{W}$, there are still many repetitive pricing and valuating works caused by different $\mathrm{BQ}$ lists and measurement rules. Further, although the engineering consulting service in China has gradually been popularized and many domestic construction projects have already realized the need and necessity of entrusting a third-party organization to carry out the whole process of engineering cost management, combined with my many years of engineering experience, the author believes that the interface of each project link is still very "weak" in the actual process: Even if the owner has provided the template in the early stage, the participating units in subsequent links are still used to adopting their own measurement methods. In the later process of compiling a bill of quantities, the third-party consulting unit (or the project-cost management team in the next link) have to re-adjust the framework of the BQ list. The repetitive and meaningless work not only has a great negative impact on efficiency and project promoting but also brings certain risks (such as data handover, a different understanding of the same project data under different thinking modes, and so on) to the project in each link.

\subsubsection{Measurement Method Characterized by Dynamic and Informatization}

In the cost-management process of German enterprises, quantity surveyors input various costs (such as material price information, labor price information, etc.) and relevant information (such as completed project information, etc.) into their internal database according to their actual engineering experience. Through the implementation of standardizedcost data-accumulation systems and the establishment of a data database, the German project-cost-management mode enables the existing project cost information to achieve its maximum value. Firstly, the previous information and data can be used as important refer- 
ences for later processes, which include investment estimations, design budget estimations, controlled bidding prices, and so on. BQ data makes available one of the best sources of real-time cost data, which can be used by quantity surveyors/cost managers to provide expert cost advice on the likely cost of future projects. Moreover, they can afford a complete cost model in a single document. Secondly, related information and data can also be the fundamental materials for techno-economic analysis, enterprise quota management, and deep research on laws about project cost. In other words, the cost data provided by the database can be retrieved, restored, and reprocessed in various ways (e.g., as distinct rates, detailed cost analyses, element unit rates, etc.) for use in the order of cost estimates and cost plans. It can also be used for benchmarking purposes.

Although there is no specialized cost engineer association in Germany, the Verein Deutscher Ingenieure (VDI, website accessed on 1 January 2022: https:/ /www.vdi.de/en/ home), as one of the world's largest technology-oriented associations and organizations, attaches great importance and emphasis to data collection related to the engineering construction field. Moreover, the data and information from the highest-cost engineer associations in the world, such as the Royal Institute of Chartered Surveyors (RICS, website accessed on 1 January 2022: https: / /www.rics.org/nl/) and the American Association of Cost Engineers (AACE, website accessed on 1 January 2022: https:/ / web.aacei.org/), are also important sources for reference of the German engineering industry. The pricing mode and measurement rule in Germany adopt the method of separation in quantity and price. The pricing basis is also supported by sufficient market research and data collection and is finally estimated by the enterprise itself. To sum up, the whole pricing method reflects the typical "dynamic" characteristics with marketization.

For a long time in the past, the phenomena of "Three Excesses" (the estimated budget exceeds the estimate; the budget exceeds the estimate; and the final budget exceeds the budget) in construction projects in China was wide-spread and particularly serious. One of the important reasons for the out-of-project investment control and the decline of project economic benefits is that the construction unit does not pay enough attention to the estimation and budget of preliminary project cost. Generally speaking, in practice, the precision of investment control in the early stage of the project is relatively low, and there may be a large number of "changes" in each subsequent process that affect the final actual project cost to a great extent. Although after years of development, problems in management and control including the "Three Excesses" have been well improved in China's engineering industry, and there are still omissions in project-cost management in third-tier and fourth-tier cities or relatively backward central and western cities in China. Moreover, there still exist many other problems, such as insufficient attention in the early stage, weak depth of controlling, low degree of personnel investment, and so on.

These problems reflect several problems existing in China's project-cost pricing model and management system:

(1) The dynamic-pricing method and measurement rule have not been fully promoted in the field of the domestic construction industry.

Although China implements the pricing and valuating mode and vigorously promotes the measurement method of "separation in quantity and price," affected by the quota mode in the last century, many domestic construction enterprises (especially construction units) still adopt the "old" method. That is to say, the project cost is determined on the basis of the unified quota issued by the state. They are a lack of flexibility in pricing and are insensitive to the consideration of market factors and environmental factors. Further, those enterprises cannot effectively control the project cost, which finally results in low investment benefit.

(2) There is no official project-cost database with dynamic release and reliable data.

Although construction enterprises in China also have the collation and release of relevant historical data, there are still many problems that need to be improved. First of all, the degree of recourse sharing is weak. Moreover, the work of unified planning, coding, and classification is also lacking and missing, intending that there is no useful database system with practical application value. Secondly, the information network is 
still needed to be deeply and further improved in every aspect. For example, although China also has a corresponding cost engineer association (China Cost Engineering Association, CCEA, website accessed on 1 January 2022: http:/ / www.ccea.pro/), no effective information can be queried in its open beta $(\mathrm{OB})$ project-cost laws database and project-cost information database. Moreover, the country-wide building-material market-price-inquiry platform and the country-wide project-cost case platform have not been opened for public testing. The developers and the owners of information resources are in a state of mutual isolation and are "fighting their own battles." The processing of information has a certain content of "randomness," and the phenomenon of "isolated islands of information" is desperately serious.

\subsection{Management Mode Characterized by "the Whole Process"}

In the German project-management thinking mode, the construction project must achieve the trinity of comprehensive control of quality, progress, and investment. Therefore, the cost engineer (also known as the "quantity surveyor," which can be abbreviated as QS) must carefully calculate the required project cost according to relevant standards and specifications and conduct all-round and whole-process project-cost management and control. To some extent, this kind of "excessive caution" is highly necessary because this cannot only directly affect the project-financing scheme in the process of investment decision-making but also can directly reflect whether the investment budget reaches the optimal level on the premise that the construction process meets all the pre-functional requirements after a series of links including decision-making, designing, bidding and construction. Hence, it is also an important factor affecting the economic and social benefits of enterprises.

In order to realize the high-quality project-cost management, there are two main solutions adopted by the German project manager or the owner: (1) Cultivate a professional team with full-cycle, whole-process, and all-round project-cost management ability within the enterprise; (2) employ qualified and experienced engineering consulting enterprises to implement the whole-process engineering-project-cost-management service. The ultimate purpose of these two methods is to realize the "one package service" of project cost, and their work duty shall begin from investment estimation, design budget estimation, and construction budget to final completion settlement and final settlement, so as to avoid the disconnection and non-cooperation between the plan and the actual construction project. It is also an effective way to avoid the ineffective work of repeated pricing and valuating by different units in the whole process of promoting the construction project.

The concept of whole-process project-cost management does not belong to a totally new field not only in China but also in the whole world, and many scholars have already conducted in-depth studies in this field. For example, Hao [33] claimed that the whole-process control of the project cost is more and more applied in the construction of the project and analyzed the necessities and strategies of the whole-process control of the construction cost of urban construction projects to provide some references for relevant researchers. Li et al. [34] aimed at the "green house" and analyzed the relationship between "sustainable" engineering and whole-process project-cost management. Some scholars [35] focused on the topic of "consulting," established an index system of advisory service evaluation, and determined the weight vector to evaluation and constructed a comprehensive evaluation model. In China, "China Engineering Cost Consulting Industry Development Report" published by CCEA also pointed out the importance of the concept of whole-process project-cost control. However, compared with other countries (especially some Western capitalist countries), there are still some problems existing in our engineering field that need to be improved and amended:

(1) Compared with other countries, China's engineering project management started relatively late. Hence, there is still a certain distance from other foreign or international engineering enterprises. Both the enterprises themselves and relevant cost managers in China are not "sensitive" to the advanced management methods and new management 
ideas. Most of them adopt the passive management mode characterized by "DeviationData Collection-Analysis-Correction," which cannot prevent possible deviations actively. In addition, there is also a large gap in talents in project-cost management in China. It is also difficult to carry out the work of truly introducing advanced management concepts into participating units (especially construction enterprises).

(2) In the domestic construction industry, there is a situation of "demand exceeding supply" in the whole-process engineering-cost-consulting enterprises. From the perspective of qualification, many engineering-cost-consulting companies in China can provide allround-cost-consulting services. However, in fact, most consulting enterprises or relevant institutions can only provide consulting services for a certain link in the construction project, meaning that the number of consulting enterprises that can truly implement and achieve the target of whole process management is still at a relatively low level. In addition, the voice of the project-cost-management team in the domestic project is relatively low, and the management of the whole project is still in the hands of the owner. The project-cost management team can only passively provide cost-management consulting services and suggestions but cannot actively participate in the construction project from the beginning.

\subsection{Summary}

The previous section (Sections 3.1 and 3.2) is a detailed comparative analysis of engineering costs between China and Germany at the theoretical level, and Table 1 in this section is to summarize the content above in relation to the authors' practical engineering experience.

Table 1. Summary of comparative analysis between China and Germany.

\begin{tabular}{|c|c|c|c|}
\hline & \multicolumn{2}{|c|}{ Difference } & \multirow{2}{*}{ Similarity } \\
\hline & China & Germany & \\
\hline \multirow{3}{*}{ Calculation of works } & $\begin{array}{l}\text { The basic composition is shown in } \\
\text { Figure } 3 \text {. }\end{array}$ & The basic composition is shown in Figure 2. & \multirow{3}{*}{$\begin{array}{l}\text { The overall } \\
\text { items of BQ are } \\
\text { similar. }\end{array}$} \\
\hline & $\begin{array}{l}\text { Basically according to the quota table } \\
\text { proposed by related specification. }\end{array}$ & $\begin{array}{l}\text { The principle is based on the drawings, that } \\
\text { is, the final completed quantity of work shall } \\
\text { prevail. }\end{array}$ & \\
\hline & $\begin{array}{l}\text { The corresponding loss is calculated } \\
\text { in works. }\end{array}$ & $\begin{array}{l}\text { The corresponding loss is calculated in the } \\
\text { unit price. }\end{array}$ & \\
\hline $\begin{array}{l}\text { Determination of unit } \\
\text { price }\end{array}$ & $\begin{array}{l}\text { Basically based on the quota ordered } \\
\text { by related departments. }\end{array}$ & $\begin{array}{l}\text { More market-oriented method for companies } \\
\text { to prepare their own unit prices according to } \\
\text { different projects under different working } \\
\text { conditions or different bidding strategies. }\end{array}$ & / \\
\hline Management mode & $\begin{array}{l}\text { Less use of advanced management } \\
\text { models. }\end{array}$ & $\begin{array}{l}\text { The advanced management mode of } \\
\text { informatization is widely used. }\end{array}$ & / \\
\hline Actual processing & $\begin{array}{l}\text { Simple and applicable without too } \\
\text { much specialized skills to complete } \\
\text { the project grouping based on } \\
\text { quantity and price. }\end{array}$ & $\begin{array}{l}\text { Requiring multiple departments to work } \\
\text { together to complete an engineering } \\
\text { assessment. }\end{array}$ & / \\
\hline
\end{tabular}

\section{Empirical Analysis Based on Case Study}

Based on previous theoretical analysis and studies, Section 3.1 will conduct empirical analysis that takes the new warehouse project of Siemens in Shenyang as an example, which further investigates the differences between China and Germany in project-cost management and control (especially in cost estimate) and provide strong support for subsequent suggestions put forward in Section 3.2. 


\subsection{Case Study}

\subsubsection{Project Overview}

Taking the new warehouse project of Siemens, which is with a total investment of more than 10 million as an example (Figure 4), the raw material warehouse covers an area of $1339 \mathrm{~m}^{2}$ and a construction area of $1629 \mathrm{~m}^{2}$. The finished product warehouse covers an area of $1779 \mathrm{~m}^{2}$ and a construction area of $2322 \mathrm{~m}^{2}$. The construction unit of the project is Siemens, and the construction unit is Shenyang Industrial Installation Engineering Co., Ltd. (SIIEC). The project was started in May 2019 and located in Shenyang, China, and now it has been completed and put into use.

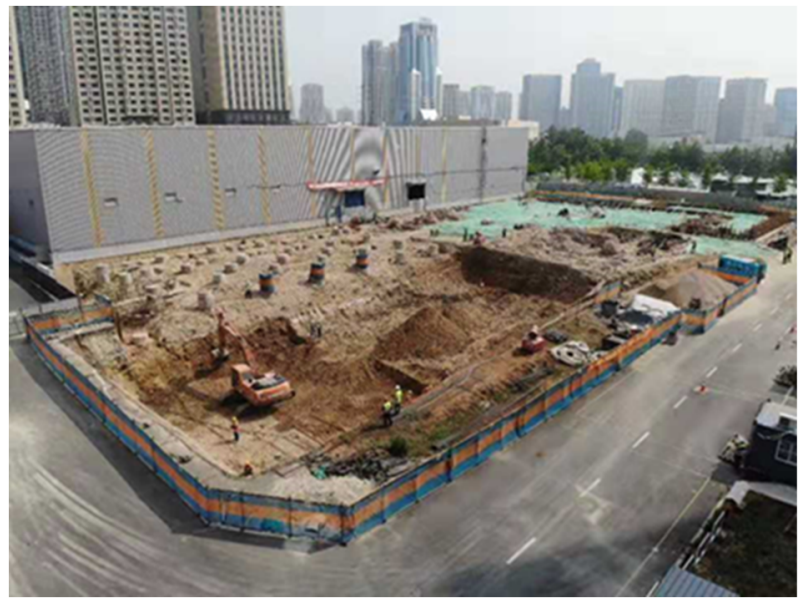

(a)

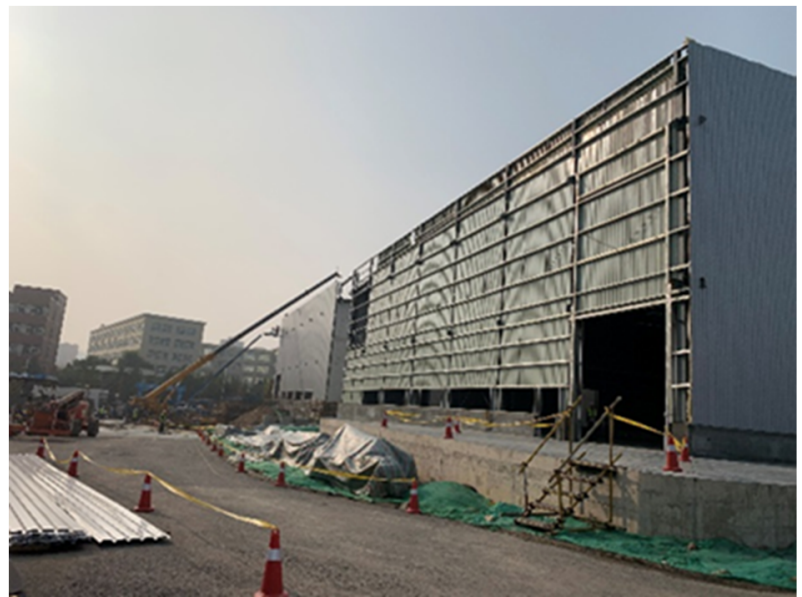

(b)

Figure 4. New warehouse project of Siemens: (a) Before construction; (b) after construction.

\subsubsection{Comparison on the Bill of Quantities}

Table 2 includes the bills of quantities for this project given by Siemens (owner) and China's construction unit SIIEC (bidder). Since the bidding of this project was mainly concentrated on the construction and installation cost in the project cost, the subsequent comparison mainly focused on the difference of construction and installation cost between China and Germany.

The following conclusions can be obtained by comparing and analyzing the above instructions with relevant specifications, standards, and other documents:

(1) The standardized rules (BQ list and measurement method) still need to be further promoted and implemented.

The code of bills of quantities and valuation for construction works (GB50500-2013) clearly explain the two classification methods: dividing according to cost components or dividing by cost formation. In this project, although Chinese enterprises have adopted the method of "dividing by cost formation" for pricing and quotation, the BQ list and its items provided by the construction unit have not been priced and valuated in full accordance with the methods recommended by specifications. For example, the cost of safety construction measures should be strictly classified as a "measure fee," but in this project Chinese construction enterprises SIIEC have listed it separately.

China has carried out drastic reform in project-cost control, BQ list items, and other aspects in project-cost management; relevant departments have also issued a large number of policy documents. However, after years of development, a large number of project participants represented by construction enterprises have not operated according to the specifications. This has brought certain adverse effects on the improvement in work efficiency of engineering-valuation practitioners, the promotion of engineering-project standardization, and the establishment of an engineering-cost information database in China.

(2) Basic composition of China and Germany are great in difference. 
As mentioned in Section 2.1.1, in terms of the types of measurement methods (or models), there indeed exist some differences between Germany and China.

Based on the authors' years of engineering experience, Chinese project-cost engineers preferred steps of determining project cost that can be concluded and summarized. The first step is to classify the measured works of the engineering project according to the project types in practice (in this project case, a Chinese construction enterprise first classifies the new warehouse engineering projects into civil engineering, decoration engineering, and outdoor engineering). Then, on the basis of preliminary classification, further preparation compilation work of a detailed bill of quantities shall be carried out.

Table 2. Comparison of BQ.

Level I

China

(Chinese Contractor BQ)
Level II

Fee of work sections and trades

\begin{tabular}{cc}
\cline { 2 - 2 } Construction and decoration & Fee of preliminaries \\
\cline { 2 - 2 } & Fee of other project \\
\cline { 2 - 2 } & Statutory fee \\
\hline
\end{tabular}

Tax

Fee of work sections and trades

\begin{tabular}{c}
\hline Fee of preliminaries \\
\hline Fee of other project \\
\hline Statutory fee
\end{tabular}

Measure fee for safety construction

Tax

Fee of preliminaries

Fee of other project

External

Statutory fee

Measure fee for safety construction

Tax

Construction communication cost, office equipment, office facilities, etc.

Preliminaries

Construction Utility Connection including temporary water and temporary electricity

Contractor's living cost

Siemens

(German Owner Budget)

\begin{tabular}{cc}
\hline & Structure works \\
\cline { 2 - 2 } Construction Works & Decoration works \\
\cline { 2 - 2 } & Miscellaneous works \\
\cline { 2 - 2 } & MEP works \\
\hline Daywork & $/$ \\
\hline VAT & $/$
\end{tabular}

German enterprises are firstly divided according to preliminaries, construction cost, and value-added tax (VAT), which is shown in Table 2. It should be noted that in this project case, the daywork item is not directly involved in pricing, hence the daywork item 
is not considered in the comparative analysis in the subsequent part. The construction cost can be further divided according to the engineering types, including structural engineering, decoration engineering, outdoor engineering, miscellaneous, etc. In addition, the pricing and valuating work in the Chinese mode is reflected and listed by multiplying the unit price by the quantity. The Siemens mode, which corresponds to the German mode and also on behalf of the "owner," chooses to reflect the total price instead.

In this project case, as QS of Siemens, the author and other engineers need to reorganize the whole $\mathrm{BQ}$ list provided by Chinese construction enterprises. That is, the author and the whole team need to totally rewrite the list according to the template provided by Siemens. This kind of repetitive, ineffective work with no real meaning has a great negative impact. Although the final project cost is consistent on the premise of adopting the two measurement methods of China and Germany, the difference between China and Germany reflected in this project is still worthy of vigilance. That is to say, it is increasingly important to put forward a "universal" project cost BQ that can be understood by local Chinese enterprises and accepted by foreign-funded enterprises.

It should be noted that in this case, although Siemens has already provided the BQ template commonly used by the company for every unit (or participant) in this project at an early stage, in the actual process the construction enterprises still use their own measurement rules and pricing steps to prepare the list, and the final $B Q$ lists submitted by them to Siemens are also based on their own BQ list template. Combined with many years of engineering experience, there are two main causes of the problems listed as follows: (1) As mentioned above, the interface relationship between the participating units of engineering projects in China is weak, and the importance of the project cost management team with high voice and decision-making power can be seen; (2) Chinese construction enterprises have difficulties in understanding and internalizing the German template provided by Siemens, which can further explain the urgency and necessity of the promotion of the universal project $B Q$.

(3) German enterprises attach importance to project-description items.

The significant difference in the bidding contract is that Siemens attaches great importance to the writing of a "description." For example, in the BQ list item of construction cost, Siemens has specially marked the description of "change" ("All unit rates shall be fixed for the duration of Contract Period and would not be adjusted even if ... "). These possible changes and ambiguities between the bidding parties are marked in both Chinese and English from the beginning with possible risks prompted in the early stage of the project so as to avoid unnecessary disputes and claims in the later stage and to improve the communication efficiency of both parties.

\subsection{Discussion Based on Engineering Project Case Located in China}

3.2.1. Establishment of a Whole-Process, Dynamic, and Information-Based Project-Cost-Management System

As mentioned above, it can be clearly seen that the modern and scientific projectcost-management-mode should be characterized by "whole-process," "full-cycle," and "dynamic pricing" and should be accompanied with a project-cost information database with reliable information sources and regularly updated data, which are the actual needs reflected by the "Three Excesses" phenomenon in actual projects in China. On this basis, the necessity of vigorously promoting an enterprise quota cannot be ignored. With the establishment of an enterprise quota and an information database owned and operated by the enterprise itself, the process of project-construction-cost management can be known clearly well during the whole process, and the problems such as winning the bid at a low price or abandoning the bid at a high price can be avoided.

\subsubsection{The Promotion and Compilation of "Universal" BQ}

As the practical problems reflected in the engineering cases in this article proposed in previous sections, whether Chinese enterprises investing in construction abroad or foreign- 
funded enterprises engaged in engineering activities in China, the emergence of different types of lists are inevitably faced by different participating units in the same project due to institutional differences. The most direct consequence of this phenomenon is the repeated work faced by the project pricing staff, and the reduction in efficiency and the emergence of hidden risks need to be noticed and highly vigilant. Furthermore, in the process of the unnecessary repeated pricing work, there may be inconsistent and contradictory results due to different pricing methods and thinking modes. Therefore, as the policies of "one belt, one road" and "reform and opening up" have been further deepened, proposing a set of "universal" BQ, which can be understood by Chinese enterprises and also accepted by foreign-funded enterprises, has become the major problem that must be solved by relevant practitioners and government departments.

In the example of Siemens mentioned above, the contractor and Siemens held a special expert meeting on the issue of "cost" in the process of finalizing the cost. The meeting brought in cost engineers and structural engineers from the front line of the project, as well as professors from universities and colleges engaged and specialized in relevant research. During the meeting, experts and scholars also mentioned that since the bidding parties adopted different quantity list templates, it had indeed brought the duplication of work in the final operation, hence the proposed "universal" quantity list is of certain practical significance.

3.2.3. Cultivation of Talents with the Advanced Management Concept, and the Development of International Engineering Companies and Project-Management Companies with Core Competitiveness

In order to truly promote the landing of the whole-process, dynamic, and informationbased project-cost-management system in China, it is necessary to improve the voice of the project cost management team in the whole project, and they should be given certain decision-making power. Secondly, the construction of a talent team with the advanced management concept and ability must be paid enough attention and attached high importance. It should be led by the government with the association of colleges, universities, industry associations, engineering companies, etc. Meanwhile, the training intensity and scale of reserved talents should be increased. The training of existing employees is also necessary so as to avoid problems such as "non-standard pricing" exposed in the case of Siemens in this study.

In addition, in order to break the gap between China and Germany in constructionproject-cost management, on the one hand, Chinese enterprises should be vigilant and make plans in combination with the analysis of the causes of relevant problems. On the other hand, engineering consulting companies, which can really provide a "one package service" should be vigorously cultivated with policy support. More importantly, domestic construction enterprises should pay much more attention to cultivating a modern project management team that can provide the whole-process, dynamic, and informationbased project-cost management. On the goal of long-term development, learning various advanced project-management experiences at home and abroad and the advantages of different project-cost modes has become the task that Chinese engineering enterprises must finish and achieve to build the enterprises into an international engineering company with core competitiveness and quickly narrow the practical gap with the top engineering companies in the world in terms of enterprise scale, operation, and management mechanism, which has a stronger practical significance under the background that China has become one of the most-important global engineering construction centers.

\section{Conclusions}

Under the background of the continuous optimization and development of the construction industry, this study compared and analyzed the differences between China and Germany in construction-project cost management, put forward some suggestions based on engineering practice, and formed the following conclusions: 
(1) There are great differences between China and Germany in project-cost management and control concept, measurement mode, BQ list, and item, etc. Although the thinking mode and principle of "separation in quantity and price" is adopted in China, the whole management process still has the characteristics of a "quota." The whole-process, dynamic, and information-based project-cost pricing and valuating method (or mode) should be one of the most-important directions of project-cost reform in the future.

(2) Combined with the differences in project-cost management of different countries, based on the engineering practice in China, it is an urgent practical problem to put forward the universal $\mathrm{BQ}$, which can be understood by local Chinese engineering enterprises and also meets the thinking mode of foreign engineers. Both governments and enterprises should pay attention to the compilation and promotion of this issue so as to provide strong support for the "going global" strategy.

(3) In terms of the reform and development of project-cost management, the goal of long-term development should be confirmed, and the reform should be further continued in a deeper degree with the absorption of various advanced experiences. With China's engineering reality, the all-round training of project-cost management talents with advanced ideas and vigorous cultivation of international engineering companies with core competitiveness also need to be highly strengthened in order to quickly narrow the gap with the top engineering companies in the world and to improve the international competitiveness of China's engineering enterprises.

Author Contributions: For the manuscript "The comparison and analysis of Chinese and German engineering cost management," there are two co-authors, who are G.L. and R.X. The first author G.L. mainly conducted the research on project-cost management and control and has made some achievements in this field. Based on his abundant research experiences, he summarized this survey and wrote the manuscript. The second author, R.X., was the supervisor of G.L. and has focused on the topic of project management, the construction engineering economy, and the project investment decision for over 10 years. R.X. has made many contributions to this field. When preparing and submitting this manuscript, she took full charge of the manuscript's quality. Consequently, she is the corresponding author of this article. All authors have read and agreed to the published version of the manuscript.

Funding: This research received no external funding.

Institutional Review Board Statement: Not applicable.

Informed Consent Statement: Not applicable.

Data Availability Statement: This research received no external data.

Conflicts of Interest: The authors declare no conflict of interest.

\section{Abbreviations}

$\begin{array}{ll}\text { BQ } & \text { Bills of Quantities } \\ \text { EPC } & \text { Engineering Procurement Construction } \\ \text { VDI } & \text { Verein Deutscher Ingenieure } \\ \text { RICS } & \text { Royal Institute of Chartered Surveyors } \\ \text { M+W } & \text { The company name of M+W Group, and it is named after the two founders' } \\ & \text { names (Karl Meissner and Paul Wurst) } \\ \text { Three Excesses } & \begin{array}{l}\text { The estimated budget exceeds the estimate; the budget exceeds the estimate; } \\ \text { the final budget exceeds the budget }\end{array} \\ \text { AACE } & \text { American Association of Cost Engineers } \\ \text { CCEA } & \text { China Cost Engineering Association } \\ \text { OB } & \text { Open Beta } \\ \text { QS } & \text { Quantity Surveyor } \\ \text { VAT } & \text { Value-Added Tax }\end{array}$




\section{References}

1. Xizhen, G.; Huimin, W. Evaluation index system of construction industry development under the high-quality development. In Proceedings of the 2021 3rd International Conference on Civil Architecture and Energy Science (CAES 2021), Hangzhou, China, 19-21 March 2021; pp. 3060-3064.

2. Zid, C.; Kasim, N.; Soomro, A.R.; Laidoune, A. The discrepancy in the construction industry of Malaysia: One of the most contributing industries in Malaysia's economy and the highest contributor of the fatal accidents. In Proceedings of the 5th International Conference on Mechanical Engineering Research 2019 (ICMER 2019), Kuantan, Malaysia, 30-31 July 2019; 788, p. 012034.

3. Forcael, E.; Ferrari, I.; Opazo-Vega, A.; Pulido-Arcas, J.A. Construction 4.0: A Literature Review. Sustainability 2020, $12,9755$. [CrossRef]

4. Kozlovska, M.; Klosova, D.; Strukova, Z. Impact of Industry 4.0 Platform on the Formation of Construction 4.0 Concept: A Literature Review. Sustainability 2021, 13, 2683. [CrossRef]

5. Dulaimi, M.F.; Ling, F.Y.Y.; Ofori, G. Engines for change in Singapore's construction industry: An industry view of Singapore's Construction 21 report. Build. Environ. 2004, 39, 699-711. [CrossRef]

6. Xingjun, Z. Construction project cost management system based on computer technology. In Application of intelligent systems in multi-modal information analytics. In Proceedings of the 2021 International Conference on Multi-Modal Information Analytics (MMIA 2021), Huhehaote, China, 23-24 April 2021; pp. 65-71.

7. Manlian Ronald, A.S.; Lumbantoruan, H. Analysis of project cost management indicators at residential buildings (Case study: Building construction project in Rusun Penggilingan Jakarta). In Proceedings of the 1st Tarumanagara International Conference on the Applications of Technology and Engineering, TICATE 2018, Jakarta, Indonesia, 22-23 November 2018.

8. Cui, B.X.; Zhang, A.L. Talking about the project cost management. In Frontiers of Green Building, Materials and Civil Engineering; Sun, D., Sung, W.P., Chen, R., Eds.; Trans Tech Publications, Ltd.: Zurich, Switzerland, 2011; pp. 4596-4599.

9. Nie, S.M.; Ren, F.; Liu, X.L. Study on Objective-total Cost Management Mode of Construction Project. In 2014 International Conference on Management Science and Management Innovation; Atlantis Press: Dordrecht, The Netherlands, 2014.

10. Yang, G. Brief description of the history and frontier areas of the development of engineering cost management. Real Estate Guide 2015, 34, 465.

11. Guan, Y.; Gu, Y.; Fang, Y. Engineering Cost Management; Geijing Institute of Technology Press: Beijing, China, 2013.

12. Zhang, S. Engineering Cost Management; Beihang University Press: Beijing, China, 2014.

13. Siemens. SIEMENS Company [EB/OL]. Available online: https://new.siemens.com/cn/zh.html (accessed on 1 January 2022).

14. Zhenlong, N. Comparative study on cost management of construction project between China and Britain. Constr. Econ. 2020, 41, 20-23.

15. Xiao, H.; Proverbs, D. The performance of contractors in Japan, the UK and the USA: A comparative evaluation of construction cost. Constr. Manag. Econ. 2002, 20, 425-435. [CrossRef]

16. Wu, S.; Wood, G.; Ginige, K.; Jong, S.W. A technical review of bim based cost estimating in UK quantity surveying practice, standards and tools. J. Inf. Technol. Constr. 2014, 19, 535-563.

17. Wao, J.O.; Flood, I. The role of quantity surveyors in the international construction arena. Int. J. Constr. Manag. 2016, 16, 126-137. [CrossRef]

18. Ishii, N.; Takano, Y.; Muraki, M. A simulation-based dynamic scheduling method in project cost estimation process. In Proceedings of the 6th International Conference on Simulation and Modeling Methodologies, Technologies and Applications, SIMULTECH 2016, Lisbon, Portugal, 29-31 July 2016; pp. 261-279.

19. Kim, M.H.; Lee, E.B.; Choi, H.S. A Forecast and Mitigation Model of Construction Performance by Assessing Detailed Engineering Maturity at Key Milestones for Offshore EPC Mega-Projects. Sustainability 2019, 11, 1256. [CrossRef]

20. Plebankiewicz, E. Model of Predicting Cost Overrun in Construction Projects. Sustainability 2018, 10, 4387. [CrossRef]

21. Lesniak, A.; Janowiec, F. Risk Assessment of Additional Works in Railway Construction Investments Using the Bayes Network. Sustainability 2019, 11, 5388. [CrossRef]

22. Budayan, C.; Dikmen, I.; Birgonul, M.T. Construction cost map of European countries. Eng. Econ. 2020, 65, 135-157. [CrossRef]

23. Vigneault, M.A.; Boton, C.; Chong, H.Y.; Cooper-Cooke, B. An Innovative Framework of 5D BIM Solutions for Construction Cost Management: A Systematic Review. Arch. Comput. Methods Eng. 2020, 27, 1013-1030. [CrossRef]

24. Lesniak, A.; Zima, K. Cost Calculation of Construction Projects Including Sustainability Factors Using the Case Based Reasoning (CBR) Method. Sustainability 2018, 10, 1608. [CrossRef]

25. Zhang, R.; Xing, J.; Ye, K.; Lu, W.; Shan, Y. Synchronicity of global construction cost indexes. Eng. Constr. Archit. Manag. 2019, 26, 367-385. [CrossRef]

26. Yongyi, S. The comparative analysis on valuation modes between China and Germany. Sci. Technol. Inf. 2006, 34, 36-37.

27. Li, Q.; Tian, Z. Construction project cost management under the mode of bill of quantities. In Proceedings of the 17th International Symposium on Advancement of Construction Management and Real Estate, CRIOCM 2012, Shenzhen, China, 17-18 November 2012; pp. 769-780.

28. Teixeira, L.; Xambre, A.R.; Figueiredo, J.; Alvelos, H. Analysis and Design of a Project Management Information System: Practical Case in a Consulting Company. Procedia Comput. Sci. 2016, 100, 171-178. [CrossRef] 
29. Liang, B.; Zhao, W. Control scheme for expressway project cost. In Proceedings of the 2020 2nd International Academic Exchange Conference on Science and Technology Innovation (IAECST 2020), Guangzhou, China, 18-20 December 2020; pp. 1121-1124.

30. Zhou, W. Construction Cost Control Method Based on BIM information Integration Platform. In Proceedings of the 6th International Conference on Smart Grid and Electrical Automation, ICSGEA 2021, Kunming, China, 29-30 May 2021; pp. 275-279.

31. Nie, S.M.; Liu, J.Y. Discussion on objective-cost planning for construction project objective total cost management. In Proceedings of the 3rd International Conference on Civil, Architectural and Hydraulic Engineering, ICCAHE 2014, Hangzhou, China, 30-31 July 2014; pp. 2323-2326.

32. He, L. Research on Formation and Implement of Construct Payment with the Mode of Valuation with bill Quantity of Construction Works; Tianjin University of Technology: Tianjin, China, 2013.

33. Jinxin, H. Research on necessities and strategies of whole process cost control of urban construction project. In Proceedings of the 2018 4th International Conference on Social Sciences, Modern Management and Economics (SSMME 2018), Chengdu, China, 22-23 June 2018.

34. Li, J.F.; Zhang, Y. The Application of the Whole Process Management in the Green Construction Project of Cost Control; Destech Publications, Inc.: Lancaster, UK, 2016.

35. Tao, P.; Li, D.M.; Luo, G. Research on the Cost Control Effectiveness in the Whole Process of Engineering Consulting; Architecture \& Building Press: Beijing: China, 2011. 